\title{
NO-dependent cGMP signalling in neurons and astrocytes
}

\author{
Jan Giesen ${ }^{1}$, Ernst-Martin Füchtbauer ${ }^{2}$, Doris Koesling ${ }^{1}$, Michael Russwurm ${ }^{*}$ \\ From 7th International Conference on cGMP Generators, Effectors and Therapeutic Implications \\ Trier, Germany. 19-21 June 2015
}

In the central nervous system, NO-dependent cGMP signalling is associated with many different developmental processes and brain functions, including neurogenesis, neuronal development and memory formation. The $\mathrm{NO} / \mathrm{cGMP}$ signalling cascade is involved in regulating pre- and postsynaptic action by facilitating glutamate release and increasing NMDAR-mediated currents, respectively. These different actions of NO/cGMP have been ascribed to the distinct subcellular localisation of the two known NO-GCs.

Immunohistochemical studies indicate a presynaptic localisation of NO-GC1, whereas $\mathrm{NO}-\mathrm{GC} 2$ is found at the postsynaptic site. Both NO-GC isoforms are required for LTP, as knock-out mice of either one of the NO-sensitive GCs show impaired induction of hippocampal and cortical LTP.

FRET-based cGMP indicators (cGi) are an important tool to analyze the temporal resolution of cGMP signals in living cells. Therefore, a transgenic mouse was generated which stably and ubiquitously expresses a cGMP indicator (cGi500). Confocal laser scanning microscopy was used to monitor cGMP signalling in primary cells from cGi500 knock-in mice.

Fast and reversible NO-induced cGMP signals were detectable in neurons and astrocytes. Maximal GSNOinduced cGMP responses were similar in both cell types. Cyclic GMP signals in neurons were elicited by approximately ten fold lower GSNO concentrations compared to astrocytes. Whether lower responses of astrocytes to exogenous applied NO could be due to lower amount of cGMP-generating enzymes or different expression pattern of PDEs will be further studied in detail.

\footnotetext{
* Correspondence: michael.russwurm@ruhr-uni-bochum.de

'Institute of Pharmacology and Toxicology, Ruhr-University-Bochum,

Bochum, Germany

Full list of author information is available at the end of the article
}

\section{Authors' details}

'Institute of Pharmacology and Toxicology, Ruhr-University-Bochum, Bochum, Germany. ${ }^{2}$ Department of Molecular Biology and Genetics Molecular Cell and Developmental Biology, Aarhus University, Denmark.

Published: 2 September 2015

doi:10.1186/2050-6511-16-S1-A55

Cite this article as: Giesen et al: NO-dependent cGMP signalling in neurons and astrocytes. BMC Pharmacology and Toxicology 2015 16(Suppl 1):A55.
Submit your next manuscript to BioMed Central and take full advantage of:

- Convenient online submission

- Thorough peer review

- No space constraints or color figure charges

- Immediate publication on acceptance

- Inclusion in PubMed, CAS, Scopus and Google Scholar

- Research which is freely available for redistribution
() Biomed Central 